Article

\title{
Structural and Quantitative Investigation of Perovskite Pore Filling in Mesoporous Metal Oxides
}

\author{
Shany Gamliel ${ }^{1,2}$, Inna Popov ${ }^{2}$, Bat-El Cohen ${ }^{1,2}$, Vladimir Uvarov ${ }^{2}$ and Lioz Etgar 1,2,* \\ 1 Institute of Chemistry, Casali Center for Applied Chemistry, The Hebrew University of Jerusalem, \\ Jerusalem 90400, Israel; shanygamliel@gmail.com (S.G.); bat-el.cohen2@mail.huji.ac.il (B.-E.C.) \\ 2 The Center of Nanoscience and Nanotechnology, The Hebrew University of Jerusalem, Jerusalem 90400, \\ Israel; innap@savion.huji.ac.il (I.P.); vladimiru@savion.huji.ac.il (V.U.) \\ * Correspondence: lioz.etgar@mail.huji.ac.il; Tel./Fax: +972-2-6585325
}

Academic Editors: Roberto Comparelli, Lucia Curri and Marinella Striccoli Received: 29 September 2016; Accepted: 9 November 2016; Published: 16 November 2016

\begin{abstract}
In recent years, hybrid organic-inorganic perovskite light absorbers have attracted much attention in the field of solar cells due to their optoelectronic characteristics that enable high power conversion efficiencies. Perovskite-based solar cells' efficiency has increased dramatically from $3.8 \%$ to more than $20 \%$ in just a few years, making them a promising low-cost alternative for photovoltaic applications. The deposition of perovskite into a mesoporous metal oxide is an influential factor affecting solar cell performance. Full coverage and pore filling into the porous metal oxide are important issues in the fabrication of highly-efficient mesoporous perovskite solar cells. In this work, we carry out a structural and quantitative investigation of $\mathrm{CH}_{3} \mathrm{NH}_{3} \mathrm{PbI}_{3}$ pore filling deposited via sequential two-step deposition into two different mesoporous metal oxides- $\mathrm{TiO}_{2}$ and $\mathrm{Al}_{2} \mathrm{O}_{3}$. We avoid using a hole conductor in the perovskite solar cells studied in this work to eliminate undesirable end results. Filling oxide pores with perovskite was characterized by Energy Dispersive X-ray Spectroscopy (EDS) in Transmission Electron Microscopy (TEM) on cross-sectional focused ion beam (FIB) lamellae. Complete pore filling of $\mathrm{CH}_{3} \mathrm{NH}_{3} \mathrm{PbI}_{3}$ perovskite into the metal oxide pores was observed down to X-depth, showing the presence of $\mathrm{Pb}$ and I inside the pores. The observations reported in this work are particularly important for mesoporous $\mathrm{Al}_{2} \mathrm{O}_{3}$ perovskite solar cells, as pore filling is essential for the operation of this solar cell structure. This work presents structural and quantitative proof of complete pore filling into mesoporous perovskite-based solar cells, substantiating their high power conversion efficiency.
\end{abstract}

Keywords: pore filling; mesoporous; perovskite; STEM-TEM; XRD

\section{Introduction}

Hybrid organic-inorganic perovskites have recently emerged as a promising light harvester material in solar cells due to their distinctive chemical and physical properties and simple synthesis routes. Hybrid perovskites are described by the general formula $\mathrm{ABX}_{3}(\mathrm{~A}=$ organic group, $\mathrm{B}=\mathrm{Pb}$ or $\mathrm{Sn}$, and $\mathrm{X}=\mathrm{I}, \mathrm{Br}, \mathrm{Cl})$; methylammonium iodide $\left(\mathrm{CH}_{3} \mathrm{NH}_{3} \mathrm{I}=\mathrm{MAI}\right)$ is the most investigated organo-metal perovskite in the field of perovskite-based solar cells [1-5].

Miyasaka et al. first used $\mathrm{MAPbI}_{3}$ in a dye-sensitized solar cell (DSSC) configuration on mesoporous $\mathrm{TiO}_{2}$, achieving a power conversion efficiency (PCE) of 3.8\% [6]. However, these cells were unstable in the liquid electrolyte and suffered from degradation. Replacement of the liquid electrolyte with a solid-hole conductor material (HTM) solved the immediate instability problem of these solar cells, and increased their PCEs to over 10\% [7]. To date, a PCE of $22.1 \%$ was demonstrated for perovskite-based solar cells [8]. PCEs of $7.6 \%$ and $10.9 \%$, respectively, were first reported for mixed halide perovskite deposited into mesoporous $\mathrm{Al}_{2} \mathrm{O}_{3}$ and $\mathrm{TiO}_{2}$ [9], demonstrating the ability of 
perovskite to efficiently transfer electrons. Therefore, perovskite-based solar cells are not restricted to mesoporous structures, and planar configuration was also demonstrated with high PCEs $[10,11]$. In addition, it has been shown that perovskite can be used both as a hole conductor and a light harvester, lowering the cost and simplifying the fabrication process. These HTM-free perovskite solar cells have PCEs of $10 \%-12.8 \%$ [12-17].

When perovskite was first introduced into solar cells, it was initially deposited via a solution process deposition technique into the mesoporous metal oxide film using a mixture of $\mathrm{PbI}_{2}$ and $\mathrm{CH}_{3} \mathrm{NH}_{3} \mathrm{I}$ in a common polar solvent. However, this technique resulted in wide variations in the performance of the photovoltaic (PV) solar cell devices due to the uncontrolled precipitation of the perovskite, which produced large morphological variations [18]. As a result, several deposition techniques have been developed for perovskite-based solar cells, including vapor deposition, vapor assisted solution process (VASP), spray deposition, and two-step deposition [19-23].

Graetzel and co-workers first introduced the two-step deposition technique in a sensitized mesoscopic perovskite solar cell [20]. In this technique, a solution of $\mathrm{PbI}_{2}$ in dimethylformamide (DMF) was dropped and spin-coated onto the metal oxide nanoparticles (NPs) and subsequently transformed into perovskite by dipping the electrode into a solution of $\mathrm{CH}_{3} \mathrm{NH}_{3} \mathrm{I}$. The two-step deposition technique produced high efficiency solar cells, demonstrated good control over the perovskite morphology, and increased reproducibility of performance $[20,21]$.

Moreover, perovskite pore filling into the scaffold's metal oxide layer has an impact on the PV performance. Snaith et al. [24] estimated the perovskite pore filling fractions into the metal oxide layer. They have found that complete perovskite pore filling improves the electron transport rate, photovoltage, and reduces recombination rate. This finding was also supported by $\mathrm{Wu}$ et al. and Nanova et al., who showed the effect of the $\mathrm{TiO}_{2}$ morphology on the PV performance $[25,26]$.

Due to the importance of the pore filling, in this work we provide direct observation of perovskite penetration into the metal oxide pores. We performed a structural and quantitative study of perovskite pore filling into mesoporous metal oxide. Cells without HTM were investigated; the perovskite was deposited using the two-step deposition technique. The use of HTM-free solar cells eliminates the filtration of the hole conductor into the metal oxide pores and enables thorough investigation, avoiding undesirable end results. Energy dispersive X-ray spectroscopy in transmission electron microscopy (EDS-TEM), TEM, scanning electron microscopy (SEM) and X-ray diffraction (XRD) were used to investigate the pore filling. This study provides better understanding of the formation and the percolation of perovskite within the porous metal oxide.

\section{Experimental}

\subsection{Material Synthesis}

$\mathrm{TiO}_{2}$ paste Dyesol, DSL-90-T was diluted with ethanol in 1:4 ratio by volume, then spin coated at $2000 \mathrm{rpm}$ for $10 \mathrm{sec}$ on top of the compact $\mathrm{TiO}_{2}$ layer and annealed at $500{ }^{\circ} \mathrm{C}$ for $30 \mathrm{~min}$. In the case of $\mathrm{Al}_{2} \mathrm{O}_{3}$ electrode, $50 \mathrm{~nm}$ particle size $\mathrm{Al}_{2} \mathrm{O}_{3}$ purchased from Sigma-Aldrich was diluted with isopropanol in 1:14 ratio by volume. The deposition and annealing conditions were the same as for $\mathrm{TiO}_{2}$.

$\mathrm{CH}_{3} \mathrm{NH}_{3} \mathrm{I}$ was synthesized as described previously [27], by reacting $30 \mathrm{~mL}$ of methylamine $(40 \%$ in methanol, TCI) and $32.3 \mathrm{~mL}$ of hydroiodic acid ( $57 \mathrm{wt} \%$ in water, Aldrich) in a $250 \mathrm{~mL}$ round bottom flask at $0{ }^{\circ} \mathrm{C}$ for $2 \mathrm{~h}$ with stirring. The precipitate was recovered by putting the solution on a rotavap and carefully removing the solvents at $50{ }^{\circ} \mathrm{C}$. The yellowish raw product of methylammonium iodide $\left(\mathrm{CH}_{3} \mathrm{NH}_{3} \mathrm{I}\right)$ was washed with ethanol by stirring the mixture for $30 \mathrm{~min}$. Then, the mixture was filtered and washed three times with diethylether. After filtration, the solid was collected and dried at $70{ }^{\circ} \mathrm{C}$ in a vacuum oven for $24 \mathrm{~h}$. 


\subsection{Device Fabrication}

$\mathrm{SnO}_{2}: \mathrm{F}$ (FTO) conducting glass ( $15 \Omega \cdot \mathrm{cm}^{-1}$ Pilkington) was etched with zinc powder and $\mathrm{HCl}$ $(37 \%)$ to obtain the desired electrode pattern. The FTO glass was then washed with ethanol, acetone, deionized water, and finally was sonicated for $15 \mathrm{~min}$. A compact layer of $\mathrm{TiO}_{2}$ (blocking layer) was then spin coated on to the FTO substrate using a solution of titanium diisopropoxidebis(acetylacetonate) (TiDIP, 75\% in isopropanol, Aldrich) in ethanol and then annealed at $500{ }^{\circ} \mathrm{C}$ for $35 \mathrm{~min}$. The $\mathrm{TiO}_{2}$ solution or the $\mathrm{Al}_{2} \mathrm{O}_{3}$ solution were spin coated subsequent to $\mathrm{TiCl}_{4}$ treatment for $30 \mathrm{~min}$ at $70{ }^{\circ} \mathrm{C}$ and annealing at $450{ }^{\circ} \mathrm{C}$ for $30 \mathrm{~min}$.

The synthesis of the $\mathrm{CH}_{3} \mathrm{NH}_{3} \mathrm{PbI}_{3}$ on the $\mathrm{TiO}_{2}$ or $\mathrm{Al}_{2} \mathrm{O}_{3}$ surface was carried out by a two-step deposition technique. First, $\mathrm{PbI}_{2}$ was dissolved in $\mathrm{DMF}(0.1 \mathrm{M})$ and dropped onto the $\mathrm{TiO}_{2}$ or $\mathrm{Al}_{2} \mathrm{O}_{3}$ film and spin coated, followed by annealing at $70{ }^{\circ} \mathrm{C}$ for $30 \mathrm{~min}$. In the second step, the cell was dipped into methylammonium solution $(0.66 \mathrm{M})$. Following the dipping step, the samples were annealed at $70{ }^{\circ} \mathrm{C}$ for another $30 \mathrm{~min}$. Finally, the back contact was deposited by evaporating $70 \mathrm{~nm}$ of gold in vacuum of $5 \times 10^{-6}$ Torr.

Structure and composition of HTM-free perovskite solar cells were analyzed with scanning electron microscopy (SEM) and scanning transmission electron microscopy (STEM), both equipped with energy dispersive X-ray spectroscopy (EDS). EDS analysis was performed on top-view samples in the FEI HR SEM Sirion (FEI, Hillsboro, OR, USA) equipped with an Oxford INCA450 EDS solid state detector (Oxford Instruments NanoAnalysis, High Wycombe, UK). TEM analysis and STEM analysis were performed on cross-sectional TEM lamellae in FEI (S)TEMTecnai F20 G² (FEI, Hillsboro, OR, USA) equipped with EDAX EDS detector (EDAX AMETEK BV, Tilburg, The Netherlands). TEM lamellae were prepared with a FEI Helios Dual Beam focused ion beam (FIB, FEI, Hillsboro, OR, USA).

\subsection{X-Ray Diffraction}

X-ray diffraction measurements were performed on the D8 Advance diffractometer (Bruker AXS, Karlsruhe, Germany) with a secondary graphite monochromator, two Soller slits, and a $0.2 \mathrm{~mm}$ receiving slit. XRD patterns within the range 3 to $752 q$ were recorded at room temperature using CuKa radiation $(\lambda=1.5418 \AA$ ) with the following measurement conditions: tube voltage of $40 \mathrm{kV}$, tube current of $40 \mathrm{~mA}$, step-scan mode with a step size of $0.02^{\circ} 2 \theta$ and counting time of $1 \mathrm{~s} / \mathrm{step}$. TOPAS-v.3 software was used for structure refinement and crystallite size calculation (TOPAS V3, General Profile and Structure Analysis Software for Powder Diffraction Data, User's Manual, Bruker AXS, Karlsruhe, Germany, 2003).

\section{Results and Discussion}

The structures of the discussed perovskite-based solar cells are presented in Figures $1 \mathrm{~A}, \mathrm{~B}$ and $2 \mathrm{~B}$, composed of FTO-coated glass/compact $\mathrm{TiO}_{2}$ layer/mesoporous metal oxide $/ \mathrm{CH}_{3} \mathrm{NH}_{3} \mathrm{PbI}_{3}$ $\left(\mathrm{MAPbI}_{3}\right) / \mathrm{Au}$. The penetration of perovskite into the mesopores of two metal oxides- $\mathrm{TiO}_{2}$, and $\mathrm{Al}_{2} \mathrm{O}_{3}$-was studied with TEM on cross-sectional lamellae prepared by FIB. Cross-section TEM images of the devices are presented in Figure 1A,B. The thicknesses of metal oxides-which demonstrate high PCEs that we studied in this work-are based on our previous reports $[15,28]$. The current voltage curves of this study's cells are shown in Figure 2A, the hole conductor free $\mathrm{TiO}_{2} / \mathrm{MAPbI}_{3}$ cell has $\mathrm{V}_{\mathrm{oc}}$ of $0.85 \mathrm{~V}$, current density (Jsc) of $18 \mathrm{~mA} / \mathrm{cm}^{2}$, fill factor (FF) of $56 \%$ with efficiency of $8.5 \%$. The hole conductor free cell based on $\mathrm{Al}_{2} \mathrm{O}_{3} / \mathrm{MAPbI}_{3}$ shows $\mathrm{V}_{\text {oc }}$ of $0.88 \mathrm{~V}$, Jsc of $13.9 \mathrm{~mA} / \mathrm{cm}^{2}$, FF of $17 \%$, with efficiency of $2.1 \%$. The photovoltaic results demonstrate that both cells are working, which strengthens the discussion in this manuscript. It is important to note that these cells are hole conductor free; in particular, in the case of the $\mathrm{Al}_{2} \mathrm{O}_{3}$-based cell, the perovskite is the only charge transporter, as will be discussed below. The s-shape in the current-voltage curve for the $\mathrm{Al}_{2} \mathrm{O}_{3}$-based cell may be due to charge accumulation in this specific device structure. The exact reason is out of the scope of this work. 

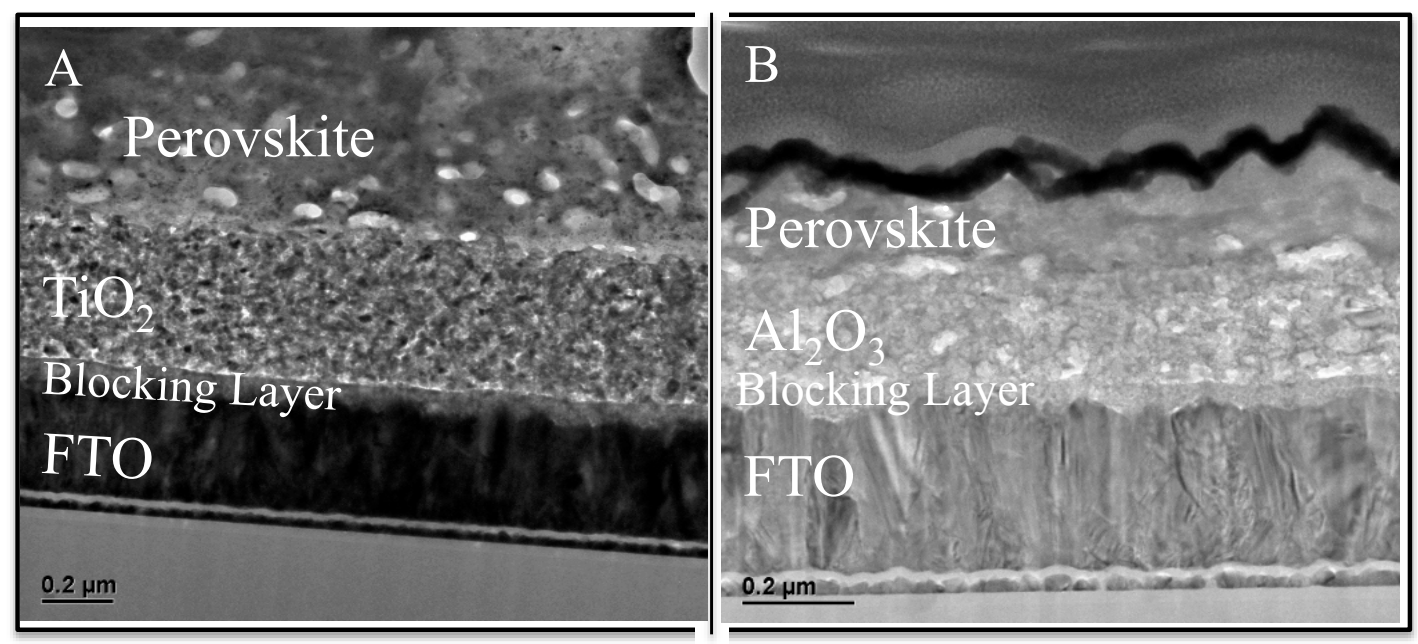

Figure 1. Transmission electron microscopy (TEM) images of cross-sectional samples prepared by focused ion beam (FIB) from (A) $\mathrm{TiO}_{2}$ / perovskite solar cell; and (B) $\mathrm{Al}_{2} \mathrm{O}_{3}$ / perovskite solar cell.

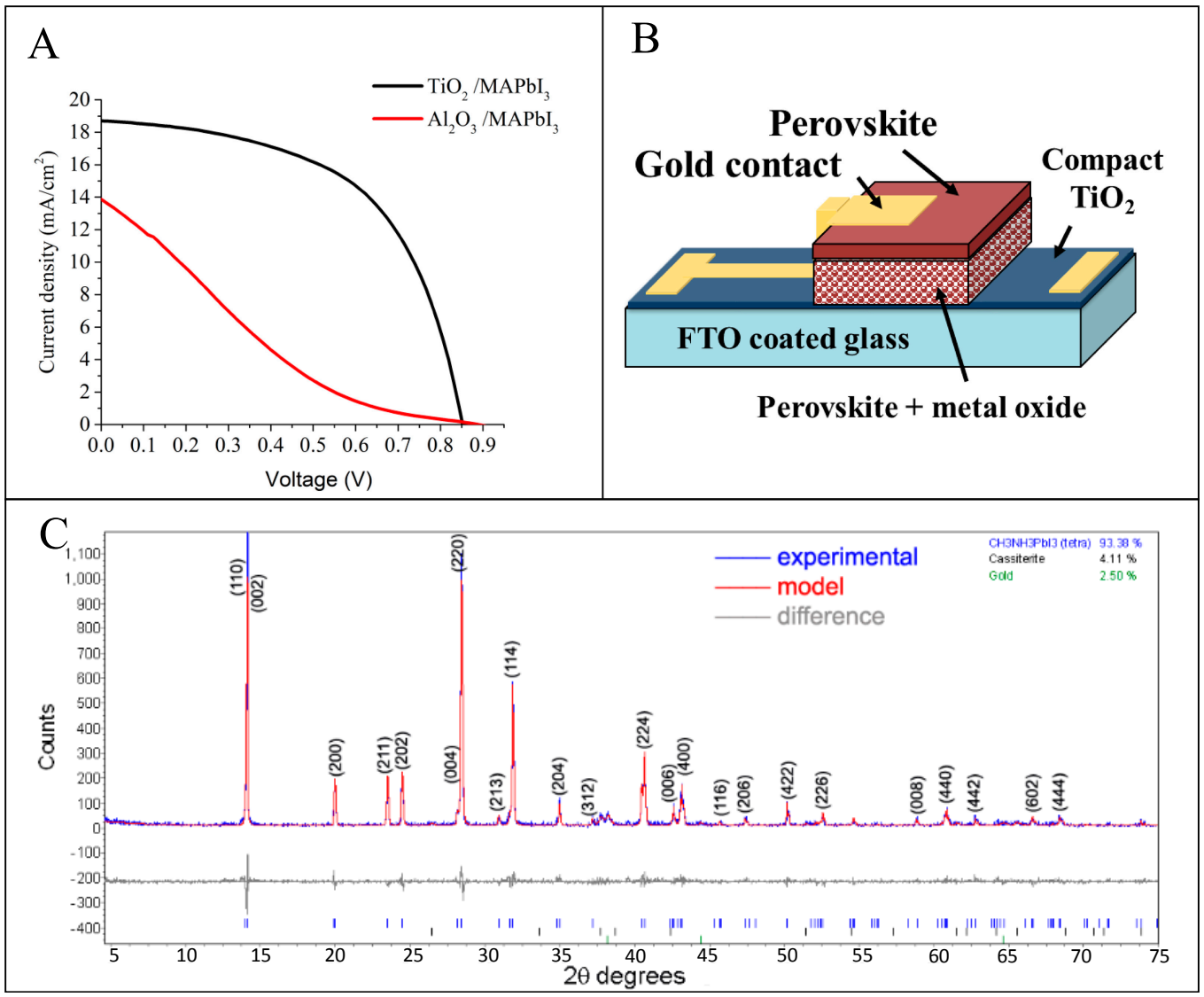

Figure 2. (A) Current-voltage curves of the study's solar cells; (B) Schematic illustration of the solar cell; (C) Graphical representation of Rietveld refinement results. Peak positions of $\mathrm{CH}_{3} \mathrm{NH}_{3} \mathrm{PbI}_{3}$, cassiterite, and gold are shown by vertical bars. FTO: $\mathrm{SnO}_{2}: \mathrm{F}$.

The graphical result of Rietveld refinement of XRD pattern acquired from the sample shown in Figure 3B is presented in Figure 2C. According to Rietveld refinement results, the synthesized $\mathrm{CH}_{3} \mathrm{NH}_{3} \mathrm{PbI}_{3}$ has a tetragonal perovskite structure with $\mathrm{I} 4 / \mathrm{mcm}$ space group and unit cell parameters $\mathrm{a}=\mathrm{b}=8.8695(16) \AA, \mathrm{c}=12.6532(24) \AA$. Calculated unit cell parameters are in a good agreement with 
the same reported by Lilliu et al. [29,30]. Crystallite size calculated using the Scherrer equation is equal to $356 \mathrm{~nm}$. This is in a good agreement with the character of electron diffraction patterns obtained from the same sample (see Figures 5 and 6).

Elemental composition of the samples was analyzed with EDS in SEM and TEM. Figure 3A,C show the EDS spectra acquired at top-view samples of the $\mathrm{TiO}_{2}$ / perovskite and the $\mathrm{Al}_{2} \mathrm{O}_{3} /$ perovskite solar cells in SEM. They reveal the presence of $\mathrm{Pb}, \mathrm{Ti}, \mathrm{Al}, \mathrm{O}, \mathrm{Ca}, \mathrm{Si}$, and $\mathrm{I}$. Calcium and silicon signals are contributions of the FTO-coated glass. Quantitative analysis of the EDS spectra shows that the atomic ratios of $\mathrm{Pb} / \mathrm{I}$ are 10:34 for $\mathrm{TiO}_{2}$ / perovskite and 4:11 for the $\mathrm{Al}_{2} \mathrm{O}_{3} /$ perovskite solar cells. The observed ratios are very close to the value of 1:3 that indicates successful deposition of stoichiometric $\mathrm{CH}_{3} \mathrm{NH}_{3} \mathrm{PbI}_{3}$ perovskite in both cases. Figure 3B,D show the SEM images of the areas from which EDS spectra were acquired. It is important to note that in both cases, large perovskite crystals of 100-200 nm can be observed, while in the case of the $\mathrm{Al}_{2} \mathrm{O}_{3}$ /perovskite, the coverage seems to be slightly better, although the PV performance is lower.

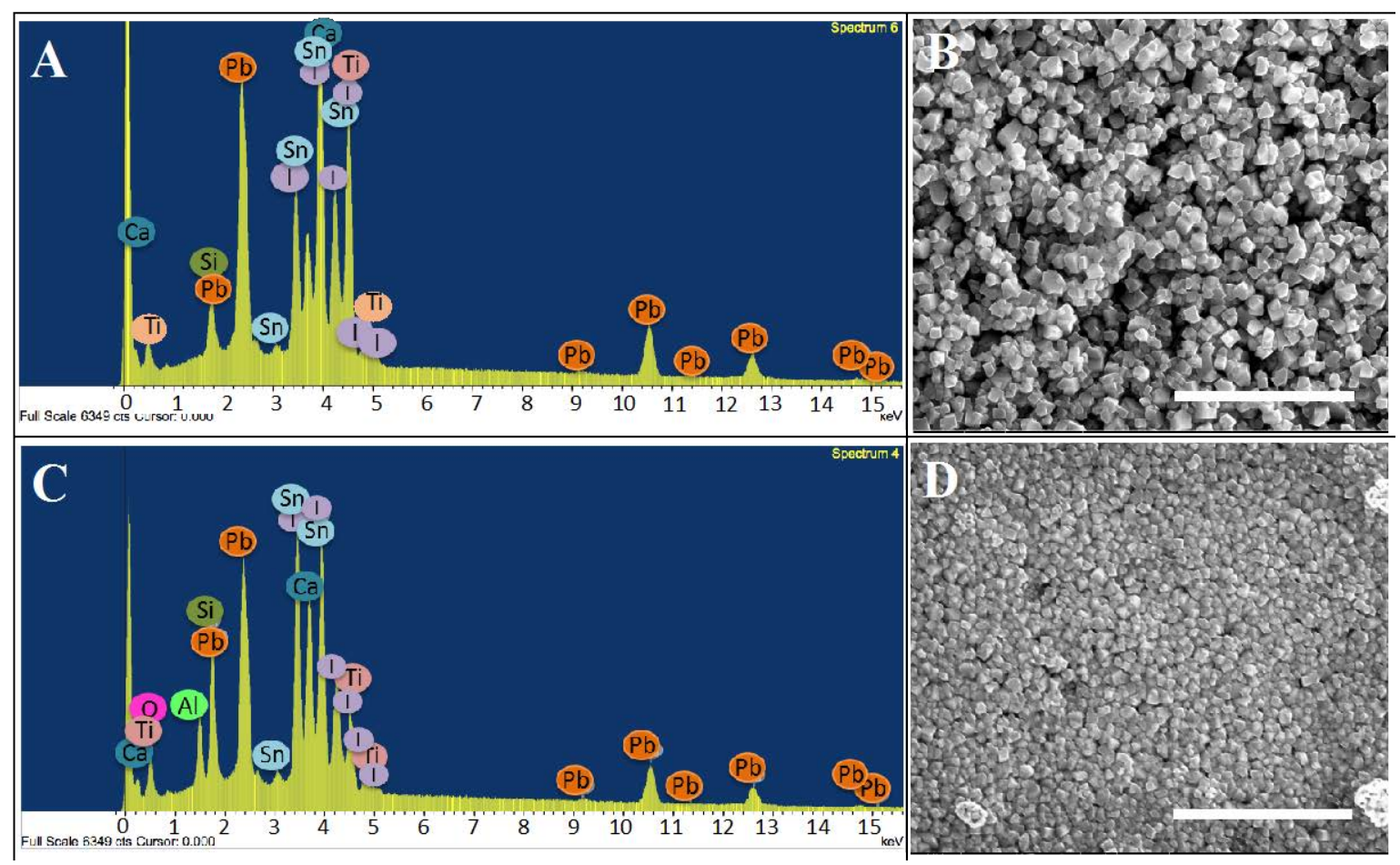

Figure 3. Energy dispersive X-ray spectroscopy (EDS) spectra acquired in scanning electron microscopy (SEM) at the top view samples of the $\mathrm{TiO}_{2}$ /perovskite (spectrum (A) and image (B)) and the $\mathrm{Al}_{2} \mathrm{O}_{3} /$ perovskite (spectrum (C) and image (D)) solar cells. Scale bars are $5 \mu \mathrm{m}$.

Additional elemental analysis of the perovskite sample was done by X-ray photoelectron spectroscopy (XPS), presented in Figure 4. The XPS shows the presence of Pb, I, C, and $\mathrm{N}$ with a ratio of 3.6 for $\mathrm{I} / \mathrm{Pb}$-further support of the successful deposition of stoichiometric $\mathrm{CH}_{3} \mathrm{NH}_{3} \mathrm{PbI}_{3}$ perovskite. The quantification results of the XPS analysis are provided in Table S1. 


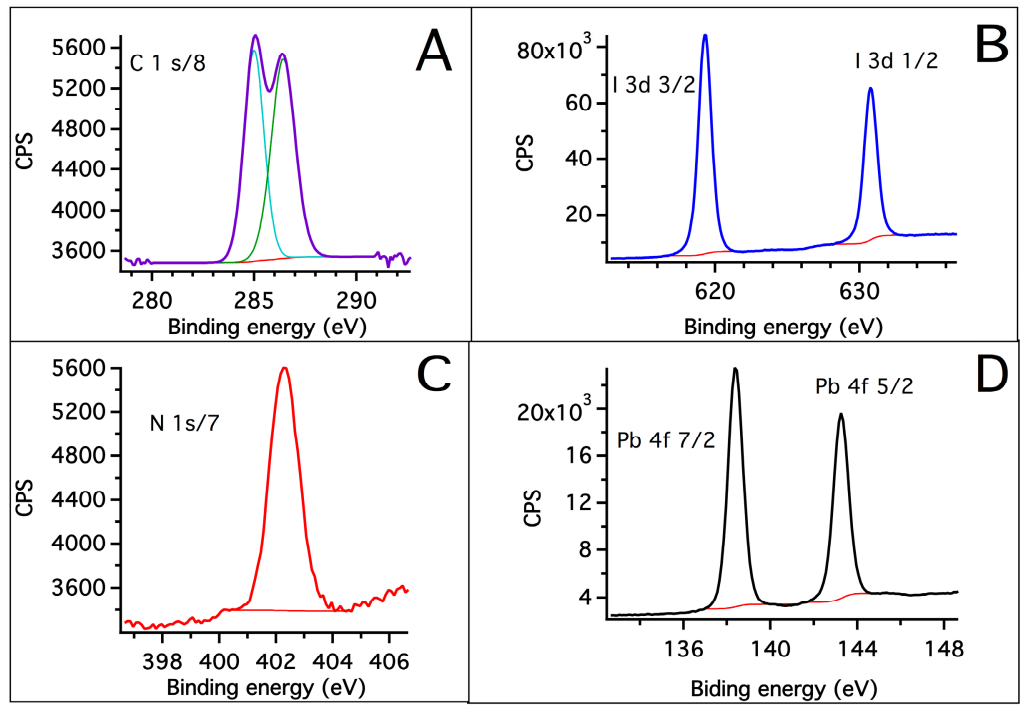

Figure 4. X-ray photoelectron spectroscopy (XPS) spectra of the perovskite sample, presenting the different elements. C1s (A), I3d 1/2 and I 3d 3/2 (B), N1s (C), Pb 4f 7/2 and Pb 4f 5/2 (D).

To investigate filling of pores by perovskite within the mesoporous metal oxides, we used STEM-based energy-dispersive $\mathrm{X}$-ray (STEM-EDS) analysis. Figures $5 \mathrm{~A}$ and $6 \mathrm{~A}$ show the location of the EDS line scan performed in the STEM-EDS line scans of $\mathrm{TiO}_{2} /$ perovskite and $\mathrm{Al}_{2} \mathrm{O}_{3}$ /perovskite solar cells, respectively. The line scanning started in the perovskite layer and ended deep in the metal oxide film.

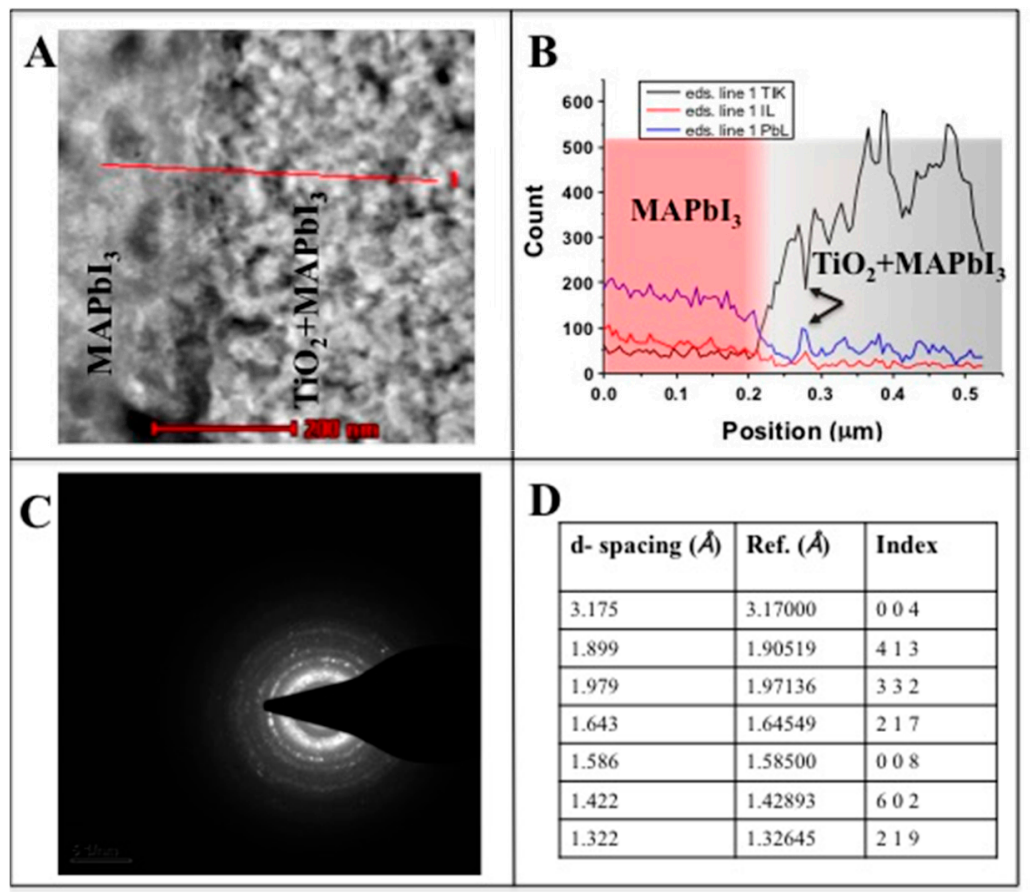

Figure 5. (A) Scanning transmission electron microscopy (STEM) image of a cross-sectioned $\mathrm{TiO}_{2}$ / perovskite solar cell; (B) Energy dispersive X-ray spectroscopy (EDS) line profiles of $\mathrm{PbL}$, IL, and TiK signals along the line shown on the STEM image; (C) Electron diffraction pattern acquired at the $\mathrm{CH}_{3} \mathrm{NH}_{3} \mathrm{PbI}_{3}$ region; (D) d-spacing between the adjacent lattice planes measured on the pattern $\mathrm{C}$. 


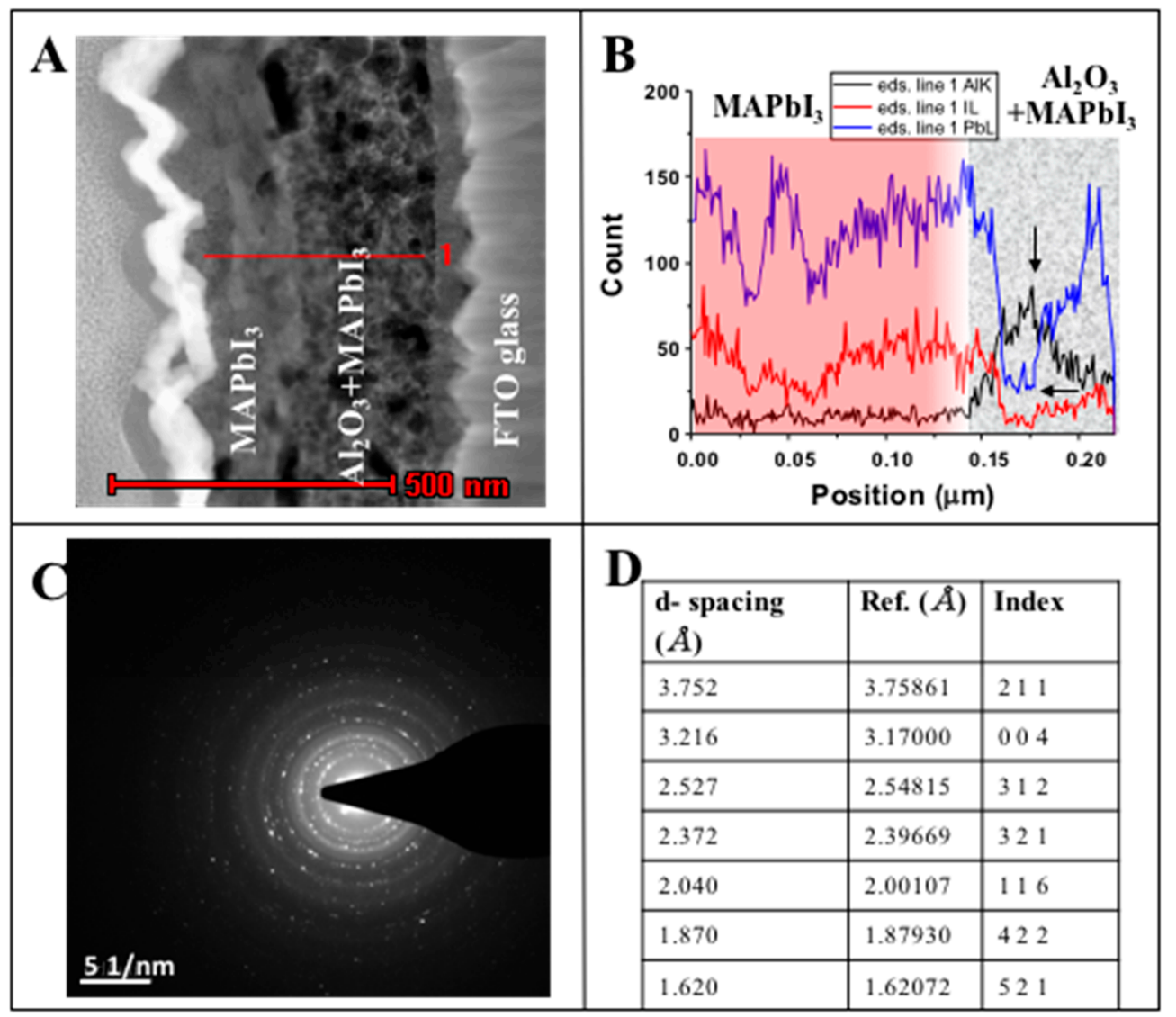

Figure 6. (A) STEM image of a cross-sectioned $\mathrm{Al}_{2} \mathrm{O}_{3}$ /perovskite solar cell; (B) EDS line profile of PbL, $\mathrm{IL}$, and AlK signals along the line shown on the STEM image; (C) Electron diffraction pattern acquired at the $\mathrm{CH}_{3} \mathrm{NH}_{3} \mathrm{PbI}_{3}\left(\mathrm{MAPbI}_{3}\right)$ region; (D) d-spacing between the adjacent lattice planes measured on the pattern $\mathrm{C}$.

The line profiles of elemental compositions of the two cells are shown in Figures 5B and 6B. (Figures S1 and S2 demonstrate additional STEM-EDS line scans of the two interfaces, which show the reliability of the results) The data demonstrate the presence of $\mathrm{Pb}$ and I throughout the perovskite and the metal oxide film, indicating that the $\mathrm{CH}_{3} \mathrm{NH}_{3} \mathrm{PbI}_{3}$ perovskite penetrates into the metal oxide films (e.g., $\mathrm{TiO}_{2}$ and $\mathrm{Al}_{2} \mathrm{O}_{3}$ ). As seen, the intensities of $\mathrm{PbL}$ and IL signals are higher at the perovskite layer, and decrease at the perovskite/metal oxide interface and at the metal oxide film. Simultaneously, a sharp increase in the TiK and AlK signals indicates the positions of perovskite/metal oxide interfaces in both samples. Within the metal oxide films, both TiK and AlK signals are changing following the mesoporous structure of oxides: the maxima appear at the locations of oxide grains, while the minima appear at the pores. It is worth noting that within the oxide layer, $\mathrm{PbL}$ and IL signals (i.e., the perovskite markers) also follow the mesoporous structure, while their signal changes are anti-phase to those of oxide markers: maxima of PbL and IL appear at pores' locations (marked with arrows for clarity in Figures 5B and 6B).

This observation is direct proof of complete filling of the oxide pores with perovskite containing both $\mathrm{Pb}$ and $\mathrm{I}$. In particular, the complete pore filling in the case of mesoporous $\mathrm{Al}_{2} \mathrm{O}_{3}$ documents the reason why this solar cell functions successfully with scaffold layer. It was previously reported [10] that the $\mathrm{Al}_{2} \mathrm{O}_{3}$ functions as a scaffold, so that charges are transported through the perovskite, which requires a complete pore filling of the $\mathrm{Al}_{2} \mathrm{O}_{3}$ film.

Although both $\mathrm{Pb}$ and I were found in the perovskite and in the metal oxide layers of TEM samples, their $\mathrm{Pb}: \mathrm{I}$ ratio measured within the perovskite was about 1:1. This value differs significantly from the stoichiometric value of 1:3 observed in SEM samples. We relate this phenomenon to the 
preferential loss of iodine during the FIB lamella preparation (as mentioned, the samples show 1:3 ratio in the EDS-SEM analysis and high crystalline structure in the XRD spectrum, where the lamella preparation was not required). Moreover, the ratio of $1: 1$ for $\mathrm{Pb}: \mathrm{I}$ also excludes the possibility of $\mathrm{PbI}_{2}$ residue in the pores.

The structure of the perovskite layer was characterized by selected area electron diffraction in TEM. The patterns obtained in $\mathrm{TiO}_{2}$ and $\mathrm{Al}_{2} \mathrm{O}_{3}$ samples are presented in Figures $5 \mathrm{C}$ and $6 \mathrm{C}$, respectively.

The d-spacing measured on these patterns are shown in Figures 5D and 6D, along with reported structural data, which shows the crystalline tetragonal perovskite $\mathrm{I} / \mathrm{mcm}$ with unit cell parameters $\mathrm{a}=\mathrm{b}=8.87 \AA$ and $\mathrm{c}=12.67 \AA$ [31-33]. Both patterns are of ring-type, which indicates the presence of a large number of randomly-oriented nanoscale crystallites in each of the perovskite layers. The strongest diffraction is observed around inter-planar spacing of 3.17-3.2 $\AA$ in both patterns, which reasonably matches the reported data for the tetragonal $\mathrm{I} 4 / \mathrm{mcm}(\mathrm{a}=\mathrm{b}=8.87 \AA, \mathrm{c}=12.67 \AA)$ perovskite $[25,28,31]$. However, the sets of diffraction reflexes appearing in both patterns do not coincide. Based on these two observations, we suggest that while the major part of nanocrystalline perovskite ensembles has the crystalline structure of the tetragonal perovskite, each of the analyzed perovskite layers contains "occasional" nanocrystals with different structures. We relate the observed structural features of perovskite to the ion beam damage at the sample preparation in FIB. The changes in the elemental composition observed with EDS should necessarily be accompanied by structural changes. To conclude, perovskite layers of $\mathrm{TiO}_{2}$ and $\mathrm{Al}_{2} \mathrm{O}_{3}$ cells are structurally similar to the tetragonal perovskite, although their electron diffraction data document different stages of structural decomposition.

\section{Conclusions}

In this work, we performed a quantitative and structural study of hybrid perovskite pore filling into mesoporous metal oxides, $\mathrm{TiO}_{2}$ and $\mathrm{Al}_{2} \mathrm{O}_{3}$. STEM-EDS characterization on cross-sectional FIB lamellae showed the presence of $\mathrm{Pb}$ and I inside the pores. SEM and XRD showed the highly crystalline structure of the tetragonal perovskite with a 1:3 ratio of $\mathrm{Pb}: \mathrm{I}$. Moreover, submicron structure of the perovskite was observed by XRD and by selected electron diffraction pattern via TEM. This work demonstrates direct proof of perovskite pore filling into mesoporous metal oxides. These results support previous assumptions about complete pore filling in mesoporous perovskite-based solar cells. The observations reported in this work are in particular important for mesoporous $\mathrm{Al}_{2} \mathrm{O}_{3}$ perovskite solar cells, as pore filling is essential for the operation of this solar cell structure.

Supplementary Materials: The following are available online at http:/ /www.mdpi.com/2073-4352/6/11/149/s1: Figure S1: Scanning transmission electron microscopy (STEM) image of a cross-sectioned $\mathrm{TiO}_{2} /$ perovskite solar cell and the energy dispersive $\mathrm{X}$-ray spectroscopy (EDS) line profiles of $\mathrm{PbL}, \mathrm{IL}$, and TiK signals along the line shown on the STEM image. $\mathrm{MAPbI}_{3}: \mathrm{CH}_{3} \mathrm{NH}_{3} \mathrm{PbI}_{3}$; Figure S2: STEM image of a cross-sectioned $\mathrm{Al}_{2} \mathrm{O}_{3} /$ perovskite solar cell and the EDS line profile of $\mathrm{PbL}, \mathrm{IL}$, and AlK signals along the line shown on the STEM image; Table S1: X-ray photoelectron spectroscopy (XPS) quantification report of the perovskite sample.

Acknowledgments: We would like to acknowledge the financial support of Israel Alternative Energy Foundation (I-SAEF), the Tashtiot Project of the Office of the Chief Scientist. We would like to thank Yafit Fleger, the head of FIB unit, Institute of Nanotechnology \& Advanced Materials (BINA) at Bar-Ilan University.

Author Contributions: Shany Gamliel conceived and designed the experiments; Bat-El Cohen performed the experiments; Vladimir Uvarov preformed the XRD measurements, Inna Popov preformed the STEM-TEM measurements and analyzed the data; Lioz Etgar planned and analyzed the experiments and wrote the manuscript.

Conflicts of Interest: The authors declare no conflict of interest.

\section{References}

1. Gratzel, M. The light and shade of perovskite solar cells. Nat. Mater. 2014, 13, 838-842. [CrossRef] [PubMed]

2. Green, M.A.; Ho-baillie, A.; Snaith, H.J. The emergence of perovskite solar cells. Nat. Photon. 2014, 8, 506-513. [CrossRef]

3. Yang, Z.; Zhang, W.-H. Organolead halide perovskite: A rising player in high-efficiency solar cells. Chin. J. Catal. 2014, 35, 983-988. [CrossRef] 
4. Jung, H.S.; Park, N.-G. Perovskite Solar Cells: From Materials to Devices. Small 2015, 11, 10-25. [CrossRef] [PubMed]

5. Leijtens, T.; Eperon, G.E.; Noel, N.K.; Habisreutinger, S.N.; Petrozza, A.; Snaith, H.J. Stability of Metal Halide Perovskite Solar Cells. Adv. Energy Mater. 2015, 5. [CrossRef]

6. Kojima, A.; Teshima, K.; Shirai, Y.; Miyasaka, T. Organometal Halide Perovskites as Visible-Light Sensitizers for Photovoltaic Cells. J. Am. Chem. Soc. 2009, 131, 6050-6051. [CrossRef] [PubMed]

7. Kim, H.-S.; Lee, C.-R.; Im, J.-H.; Lee, K.-B.; Moehl, T.; Marchioro, A.; Moon, S.-J.; Baker, R.-H.; Yum, J.-H.; Moser, J.E.; et al. Lead iodide perovskite sensitized all-solid-state submicron thin film mesoscopic solar cell with efficiency exceeding 9\%. Sci. Rep. 2012, 2, 591. [CrossRef] [PubMed]

8. National Renewable Energy Laboratories NREL. Available online: http://www.nrel.gov/ncpv/images / efficiency_chart.jpg (accessed on 28 October 2016).

9. Lee, M.M.; Teuscher, J.; Miyasaka, T.; Murakami, T.N.; Snaith, H.J. Efficient Hybrid Solar Cells Based on Meso-Superstructured Organometal Halide Perovskites. Science 2012, 338, 643-647. [CrossRef] [PubMed]

10. Liu, D.; Timothy, L. Kelly, perovskite solar cells with a planar heterojunction structure prepared using room-temperature solution processing techniques. Nat. Photon. 2014, 8, 133-138. [CrossRef]

11. Docampo, P.; Ball, J.M.; Darwich, M.; Eperon, G.E.; Snaith, H.J. Efficient organometaltrihalide perovskite planar-heterojunction solar cells on flexible polymer substrates. Nat. Commun. 2013, 4, 2761. [CrossRef] [PubMed]

12. Etgar, L.; Peng, G.; Xue, Z.; Liu, B.; Nazeeruddin, M.K.; Grätzel, M. Mesoscopic $\mathrm{CH}_{3} \mathrm{NH}_{3} \mathrm{PbI}_{3} / \mathrm{TiO}_{2}$ heterojunction solar cell. J. Am. Chem. Soc. 2012, 134, 17396-17399. [CrossRef] [PubMed]

13. Laben, W.A.; Etgar, L. Depleted hole conductor-free lead halide iodide heterojunction solar cell. Energy Environ. Sci. 2013, 6, 3249-3253. [CrossRef]

14. Aharon, S.; Gamliel, S.; Cohen, B.; Etgar, L. Depletion region effect of highly efficient hole conductor free $\mathrm{CH}_{3} \mathrm{NH}_{3} \mathrm{PbI}_{3}$ perovskite solar cells. Phys. Chem. Chem. Phys. 2014, 16, 10512-10518. [CrossRef] [PubMed]

15. Cohen, B.E.; Gamliel, S.; Etgar, L. Parameters influencing the deposition of methylammonium lead halide iodide in hole conductor free perovskite-based solar cells. Appl. Mater. 2014, 2, 081502. [CrossRef]

16. Shi, J.; Dong, J.; Lv, S.; Xu, Y.; Zhu, L.; Xiao, J.; Xu, X.; Wu, H.; Li, D.; Luo, Y.; et al. Hole-conductor-free perovskite organic lead iodide heterojunction thin-film solar cells: High efficiency and junction property. Appl. Phys. Lett. 2014, 104, 063901. [CrossRef]

17. Mei, A.; Li, X.; Liu, L.; Ku, Z.; Liu, T.; Rong, Y.; Xu, M.; Hu, M.; Chen, J.; Yang, Y.; et al. A hole-conductor-free, fully printable mesoscopic perovskite solar cell with high stability. Science 2014, 345, 295-298. [CrossRef] [PubMed]

18. Liul, M.; Johnston, M.B.; Snaith, H.J. Efficient planar heterojunction perovskite solar cells by vapour deposition. Nature 2013, 501, 395-399.

19. Im, J.-H.; Jang, I.-H.; Pellet, N.; Grätzel, M.; Park, N.-G. Growth of CH3NH3PbI3 cuboids with controlled size for high-efficiency perovskite solar cells. Nat. Nanotechnol. 2014, 9, 927-932. [CrossRef] [PubMed]

20. Burschka, J.; Pellet, N.; Moon, S.-J.; Humphry-Baker, R.; Gao, P.; Nazeeruddin, M.K.; Graetzel, M. Sequential deposition as a route to high-performance perovskite-sensitized solar cells. Nature 2013, 499, 316. [CrossRef] [PubMed]

21. Chen, Q.; Zhou, H.; Hong, Z.; Luo, S.; Duan, H.-S.; Wang, H.-H.; Liu, Y.; Li, G.; Yang, Y. Planar heterojunction perovskite solar cells via vapor-assisted solution process. J. Am. Chem. Soc. 2014, 136, 622-625. [CrossRef] [PubMed]

22. Barrows, A.T.; Pearson, A.J.; Kwak, C.K.; Dunbar, A.D.F.; Buckley, A.R.; Lidzey, D.G. Efficient planar heterojunction mixed-halide perovskite solar cell deposited via spray deposition. Energy Environ. Sci. 2014, 7, 2944-2950. [CrossRef]

23. Gamliel, S.; Dymshits, A.; Aharon, S.; Terkieltaub, E.; Etgar, L. Micrometer Sized Perovskite Crystals in Planar Hole Conductor Free Solar Cells. J. Phys. Chem C 2015, 34, 19722-19728. [CrossRef]

24. Leijtens, T.; Lauber, B.; Eperon, G.E.; Stranks, S.D.; Snaith, H.J. The Importance of Perovskite Pore Filling in Organometal Mixed Halide Sensitized $\mathrm{TiO}_{2}$-Based Solar Cells. J. Phys. Chem. Lett. 2014, 7, 1096-1102. [CrossRef] [PubMed]

25. Wu, Y.; Chen, W.; Yue, Y.; Liu, J.; Bi, E.; Yang, X.; Islam, A.; Han, L. Consecutive Morphology Controlling Operations for Highly Reproducible Mesostructured Perovskite Solar Cells. ACS Appl. Mater. Interfaces 2015, 7, 20707-20713. [CrossRef] [PubMed] 
26. Nanova, D.; Kast, A.K.; Pfannmller, M.; Muller, C.; Veith, L.; Wacker, I.; Agari, M.; Hermes, W.; Erk, P.; Kowalsky, W.; et al. Unraveling the Nanoscale Morphologies of Mesoporous Perovskite Solar Cells and Their Correlation to Device Performance. Nano Lett. 2014, 14, 2735-2740. [CrossRef] [PubMed]

27. Jeong, H.; Jaehoon, C.; Seung, J.K.; Nam, G.P. Synthesis, structure, and photovoltaic property of a nanocrystalline $2 \mathrm{H}$ perovskite-type novel sensitizer $\left(\mathrm{CH}_{3} \mathrm{CH}_{2} \mathrm{NH}_{3}\right) \mathrm{PbI}_{3}$. Nanoscale Res. Lett. 2012, 7, 353.

28. Dymshits, A.; Rotem, A.; Etgar, L. High voltage in hole conductor free organo metal halide perovskite solar cells. J. Mater. Chem. A 2014, 2, 20776-20781. [CrossRef]

29. Lilliu, S.; Dane, T.G.; Alsari, M.; Griffin, J.; Barrows, A.T.; Dahlem, M.S.; Friend, R.H.; Lidzey, D.G.; Macdonald, J.E. Mapping morphological and structural properties of lead halide perovskites by scanning nanofocus XRD. Adv. Funct. Mater. 2016. [CrossRef]

30. Barrows, A.T.; Lilliu, S.; Pearson, A.J.; Babonneau, D.; Dunbar, A.D.F.; Lidzey, D.G. Monitoring the Formation of a $\mathrm{CH} 3 \mathrm{NH} 3 \mathrm{PbI} 3-x \mathrm{Cl} x$ Perovskite during Thermal Annealing Using X-ray Scattering. Adv. Funct. Mater. 2016, 26, 4934-4942. [CrossRef]

31. Kawamura, Y.; Mashiyama, H.; Hasebe, K. Structural Study on Cubic-Tetragonal Transition of $\mathrm{CH}_{3} \mathrm{NH}_{3} \mathrm{PbI}_{3}$. J. Phys. Soc. Jpn. 2012, 71, 1694-1697. [CrossRef]

32. Baikie, T.; Fang, Y.; Kadro, J.M.; Schreyer, M.; Wei, F.; Mhaisalkar, S.G.; Graetzel, M.; White, T.J. Synthesis and crystal chemistry of the hybrid perovskite $\left(\mathrm{CH}_{3} \mathrm{NH}_{3}\right) \mathrm{PbI}_{3}$ for solid-state sensitized solar cell applications. J. Mater. Chem. A 2013, 1, 5628-5641. [CrossRef]

33. Im, J.-H.; Lee, C.-R.; Lee, J.-W.; Park, S.-W.; Park, N.-G. 6.5\% efficient perovskite quantum-dot-sensitized solar cell. Nanoscale 2011, 3, 4088-4093. [CrossRef] [PubMed]

(C) 2016 by the authors; licensee MDPI, Basel, Switzerland. This article is an open access article distributed under the terms and conditions of the Creative Commons Attribution (CC-BY) license (http://creativecommons.org/licenses/by/4.0/). 